\title{
Anticancer effect of the traditional Chinese medicine herb Maytenus compound via the EGFR/PI3K/AKT/GSK3 $\beta$ pathway
}

\author{
Baozhen Zeng ${ }^{1,2 \#}$, Chunlei Ge ${ }^{1 \#}$, Wentao Zhao ${ }^{1 \#}$, Kaicong Fu ${ }^{3}$, Lin $\mathrm{Liu}^{3}$, Zhuying Lin ${ }^{4}$, Qiaofen Fu ${ }^{1}$, \\ Zhen $\mathrm{Li}^{1}$, Ruilei $\mathrm{Li}^{1}$, Huan Guo ${ }^{4}$, Chunyan $\mathrm{Li}^{1,2}$, Liufang $\mathrm{Zhao}^{1}$, Hongyan $\mathrm{Hu}^{1}$, Hanyu Yang ${ }^{3}$, \\ Wenhua Huang ${ }^{5}$, Youguang Huang ${ }^{2}$, Xin Song ${ }^{1,2}$
}

${ }^{1}$ Department of Cancer Biotherapy Center, Third Affiliated Hospital of Kunming Medical University (Tumor Hospital of Yunnan Province), Kunming 650118, China; ${ }^{2}$ Department of Yunnan Tumor Research Institute, the Third Affiliated Hospital of Kunming Medical University, Kunming 650118, China; ${ }^{3}$ Department of Traditional medicine research laboratory, Puer Traditional Ethnomedicine Institute, Puer 665000, China; ${ }^{4}$ Department of Oncology Yan'An Hospital of Kunming City, Kunming 650118, China; ${ }^{5}$ Department of Anatomy, Guangdong Provincial Key Laboratory of Medical Biomechanics, School of Basic Medical Science, Southern Medical University, Guangzhou 510515, China

Contributions: (I) Conception and design: B Zeng, C Ge, X Song; (II) Administrative support: K Fu, W Huang, Y Hang, X Song; (III) Provision of study materials or patients: W Zhao, L Liu, Z Lin, Q Fu; (IV) Collection and assembly of data: Z Li, R Li, H Guo, C Li; (V) Data analysis and interpretation: L Zhao, H Hu, H Yang; (VI) Manuscript writing: All authors; (VII) Final approval of manuscript: All authors.

\#These authors contributed equally to this work.

Correspondence to: Prof. Xin Song. Department of Cancer Biotherapy Center, Third Affiliated Hospital of Kunming Medical University (Tumor Hospital of Yunnan Province), No. 519, Kunzhou Road, Xishan District, Kunming 650118, China. Email: songxin_68@126.com; Prof. Youguang Huang. Department of Yunnan Tumor Research Institute, the Third Affiliated Hospital of Kunming Medical University, No. 519, Kunzhou Road, Xishan District, Kunming 650118, China. Email: huangyouguang2008@126.com; Prof. Wenhua Huang. Department of Anatomy, Guangdong Provincial Key Laboratory of Medical Biomechanics, School of Basic Medical Science, Southern Medical University, No. 1023, Shatainan Road, Baiyun District, Guangzhou 510515, China. Email: huangwenhua2009@139.com.

Background: Cancer is a leading cause of death worldwide; folk anticancer medicinal plants have applied for cancer treatment. The Maytenus compound tablet as traditional Chinese compound medicine has been approved for alleviating hyperplasia of mammary glands, whether it can inhibit cancer still unknown. The study was to evaluate the anticancer activity of the Maytenus compound tablet.

Methods: MTS assay evaluated the anti-proliferation effect of the Maytenus compound on H226, A2058, $786 \mathrm{O}$ and HeLa cancer cells and two normal epithelial cell lines, namely, 16HBE and Hecate. Nude mouse xenograft tumor model using H226 and HeLa cells examined the drug's anticancer effect in vivo. Western blot assay studied the possible mechanism.

Results: The Maytenus compound indicated obvious ability to against proliferation in four strains of cancer cells, particularly against H226 cells by an IC50 of $85.47 \pm 10.06 \mu \mathrm{g} / \mathrm{mL}$ and against HeLa cells by an IC50 of $128.74 \pm 17.46 \mu \mathrm{g} / \mathrm{mL}$. However, it had a low cytotoxicity in human normal epithelial cell lines $16 \mathrm{HBE}$ with an IC50 of $4,555.86 \pm 25.21 \mu \mathrm{g} / \mathrm{mL}$ and Hecate with an IC50 of $833.56 \pm 181.88 \mu \mathrm{g} / \mathrm{mL}$. The Maytenus compound at the $2.45 \mathrm{~g} / \mathrm{kg}$ oral dosages inhibited the proliferation of H226 cells and HeLa cells in nude mouse with inhibitory rates of $36.06 \%$ and $26.45 \%$, respectively, and no organ toxicity. The Maytenus compound could significantly downregulate the expression of pEGFR, pPI3K, pAKT, pGSK3 $\beta, \beta$-catenin, and c-MYC and upregulate the protein expression of GSK3 $\beta$.

Conclusions: The Maytenus compound has significant anticancer activities against human cancer H226 and HeLa cells both in vitro and in vivo, highlighting it may be an anticancer medicine.

Keywords: Maytenus compound; traditional Chinese medicine; anticancer; mechanisms

Submitted Feb 18, 2019. Accepted for publication Aug 28, 2019.

doi: $10.21037 /$ tcr.2019.09.30

View this article at: http://dx.doi.org/10.21037/tcr.2019.09.30 


\section{Introduction}

Cancer mortality rate ranks the first around world and has become the major public health problem (1). Although there are many ways to treat cancer, it is still a difficult global problem to overcome. Nowadays, traditional anticancer medicinal plants have drawn growing interest as novel drugs because more and more studies have found that they have potentiality been as medicines for cancer prevention and therapy (2).

The Maytenus compound tablet is a folk traditional medicine used by Lahu minority people in Yunnan Province of China. It consists of six herb medicines, including Maytenus austroyunnanensis (S. J. Pei et al., Y. H. Li) and Maytenus hookeri Loes (herein afterward referred to as Maytenus), Sargrassum, Oldenlandia Diffusa Willd, Balanophora Harlandii Hook.f, Tripterygium hypoglaucum Hutch and Paris polyphylla. These plants are predominantly distributed in Yunnan province of China. Maytenus is used in Chinese traditional medicine for therapy of digestive inflammatory disorders such as ulcers $(3,4)$, and it has antiparasitic activities (5). In recent years, the leaf extract of Maytenus in Brazilian has been reported to possess anticancer activity (6). Previously, maytansine, the chemical constituent of Maytenus, played important roles in anticancer effect by affecting micro-tubules $(7,8)$. T-DM1 (Trastuzumab emtansine) including DM1, one of the maytansine derivative, has strong effect against HER2positive breast cancer as a novel drug (9). Trichothecin (TCN), isolated from an endophytic fungus of Maytenus, can induce G0/G1 cell cycle arrest and activate proapoptotic proteins, promoting cancer cell apoptosis (10).

The Maytenus compound tablet has been approved for alleviating hyperplasia of mammary glands [approval number: Dian drug (Z)05J02424)] in China, and it is a traditional Chinese compound medicine, there are no reports about its anti-cancer function. Therefore, the goal of this study was to evaluate the anticancer activity of the Maytenus compound tablet in both vitro and in vivo, further investigate the underlying mechanism.

\section{Methods}

\section{Preparation of Maytenus compound}

Per gram Maytenus compound tablet [(Z05J02424), Puer Traditional Ethnomedicine Institute, China] included Maytenus $235 \mathrm{mg}$, Sargrassum $176.5 \mathrm{mg}$, Oldenlandia Diffusa Willd 176.5 mg, Balanophora Harlandii Hook.f.,
$176.5 \mathrm{mg}$, Tripterygium Hypoglaucum Hutch $176.5 \mathrm{mg}$, and Paris Polyphylla $59 \mathrm{mg}$. The tablets were grinded into powder and dissolved in Dimethyl Sulfoxide (DMSO; D2650, Sigma, USA) for further tests. And the control is $0 \mu \mathrm{g} / \mathrm{mL}$ of Mytenus, which medium add with Dymethyl sulfoxide.

\section{Cell lines}

In this study, we used several strains of human cancer cell lines, involving lung cancer cell H226, melanoma cell A2058, kidney cancer cell 786O, cervical cancer cell HeLa, normal epithelial cell 16HBE and Hecate. All cancer cell lines were obtained from the ATCC Bioresource Center. H226, $786 \mathrm{O}$ and 16HBE cells were cultured with RPMI 1640 (Gibco, USA) including 10\% FBS (Gibco, USA). A2058 cells were cultured with DMEM F12 (Gibco, USA) including 10\% FBS. HeLa and Hecate cells were cultured with DMEM high glucose (Gibco, USA) including 10\% FBS.

\section{Determination of IC50}

Briefly, 3,000 cells and $150 \mu \mathrm{L}$ medium were seeded each well in 96-well culture plates, each group had six duplicate wells. After cells were seeded for $24 \mathrm{~h}$, they were treated with the Maytenus compound in designated doses $(4,800,2,400,1,200$, $600,300,150,75,37.5,18.75,9.375,4.6875$ and $0 \mu \mathrm{g} / \mathrm{mL})$ for $72 \mathrm{~h}$. Then, per well was added $30 \mu \mathrm{L}$ of MTS [3-(4,5dimethylthiazol-2-yl)-5-(3- carboxymethoxyphenyl)-2 -(4-sulfophenyl) -2H- tetrazolium; G111A, Promega, USA], and full wavelength scanner (Varioskan Flash, Thermo Fisher, USA) was used to measured absorbance of each sample at $490 \mathrm{~nm}$ after they were incubated in an cell incubator for $2 \mathrm{~h}$. IC50 is the concentration that is required to inhibit $50 \%$ of cell growth; Bliss method was used calculate IC50 from survival curves (11).

\section{Cell proliferation}

MTS assay was also used to quantify cell proliferation. In brief, 2,000 cells and $150 \mu \mathrm{L}$ medium were seeded each well in 96-well culture plates, and each group had six duplicate wells, incubated in complete medium with different concentrations of the Maytenus compound. Over a 4-day period, every $24 \mathrm{~h}$, each well was added $30 \mu \mathrm{L}$ of MTS, and full wavelength scanner was used to measured absorbance of each sample at $490 \mathrm{~nm}$ after they were incubated in a cell incubator for $2 \mathrm{~h}$. 


\section{Clonogenic assays}

One thousand and five hundred cells and $1.5 \mathrm{~mL}$ medium were seeded each well in 6-well culture plates each group had three duplicate wells. After cells were seeded for 24 $\mathrm{h}$, they were treated with the different concentrations of Maytenus compound for $72 \mathrm{~h}$. Then, cells were incubated continuously without the drug effect for approximately 10 days. After PBS washed cells three times, methanol fixed cells for $20 \mathrm{~min}$ and hematoxylin stained cells for $5 \mathrm{~min}$, then cells were washed clean with $\mathrm{ddH}_{2} \mathrm{O}$, aired, and naked clones were counted.

\section{In vivo antitumor tests}

Five-week-old female athymic BALB/c nude mice were housed in pathogen-free conditions according to the Guide for the Care and Use of Laboratory Animals. We generated the xenograft model by injection of $2 \times 10^{6} \mathrm{H} 226$ cells or $1 \times 10^{6} \mathrm{HeLa}$ cells into the right armpit of nude mice. The mice were divided into control $\left(\mathrm{ddH}_{2} \mathrm{O}\right)$ and treatment group $(2.45 \mathrm{~g} / \mathrm{kg}$ dose of the Maytenus compound), randomly. And the $2.45 \mathrm{~g} / \mathrm{kg}$ dose is determined according to the results of the toxicological experiment by Puer Traditional Ethnomedicine Institute (Puer, China). The $\mathrm{ddH}_{2} \mathrm{O}$ and the Maytenus compound were both intragastrically administered once a day, for a total of 30 (H226) or 22 days (HeLa). During this period, mice body weight and the long diameter (a) and short diameter (b) of tumors were measured and recorded every two days. Tumor volumes $\left(\mathrm{cm}^{3}\right)$ were calculated according to the formula: volume $=\left(a \times b^{2}\right) / 2$. The tumors, liver, spleen and kidney were collected and weighed after the mice were sacrificed by cervical dislocation. All procedures were supported by the Animal Care and Research Committee of Kunming Medical University.

All the isolated tumor tissues were cut into $4 \mu \mathrm{m}$ sections by fixing in the formalin and embedding in paraffin, sections were baked at $70{ }^{\circ} \mathrm{C}$ for $1 \mathrm{~h}$, immersed in xylene for $20 \mathrm{~min}$, and rehydrated in alcohol, followed by staining with hematoxylin-eosin.

\section{Western blotting}

Cells treated with the Maytenus compound for $72 \mathrm{~h}$ were collected and lysed completely in cold RIPA buffer (89900, Pierce, USA), BCA protein assay kit (23227, Thermo Fisher, USA) was measured protein concentration.
For each sample protein, $50 \mu \mathrm{g}$ were separated on SDSpolyacrylamide gels and transferred onto PVDF membranes (ISEQ00010, Millipore, USA) by electroblotting. Membranes were blocked with $8 \%$ non-fat milk in $0.1 \%$ TBST for $2 \mathrm{~h}$ at ambient temperature, then added primary antibody incubated for $15 \mathrm{~h}$ at $4{ }^{\circ} \mathrm{C}$. Primary antibodies: EGFR (CST, \#4405), pEGFR (CST, \#4407), PI3K (ab189403), pPI3K (ab182651), AKT (ab8932), pAKT (ab179463), GSK3 $\beta$ (CST, \#9832), pGSK3 $\beta{ }^{\text {Ser9 }}$ (CST, \#5558), $\beta$-catenin (CST, \#8480) and c-MYC (ab56), GAPDH (CST, \#2125). Secondary antibodies labeled with horseradish peroxidase (HRP) (1:8,000, CST, \#7076) were incubated membranes for $1 \mathrm{~h}$ at room temperature. After above, the visualized blots were detected by ECL (RPN2135, GE healthcare, UK).

\section{Statistical analysis}

Data are expressed as the mean \pm SD (standard deviation) and evaluated by independent $t$-test with SPSS version 18.0 software and Prism 5 (GraphPad Software, USA). The differences were considered statistically significant at $\mathrm{P}<0.05$.

\section{Results}

\section{In vitro antitumor activity}

Proliferation inhibitory effect at $72 \mathrm{~h}$ against four different human cancer cell lines (H226, A2058, $786 \mathrm{O}, \mathrm{HeLa}$ ) and human normal epithelial cell lines (16HBE, Hecate) were detected by MTS assay. As shown in Figure 1A, the Maytenus compound inhibited the growth of the four cancer cell lines in a dosedependent manner. In addition, the Maytenus compound revealed a stronger proliferation inhibitory effect of $\mathrm{H} 226$ cells with an IC50 of $85.47 \pm 10.06 \mu \mathrm{g} / \mathrm{mL}$ and of HeLa with an IC50 of $128.74 \pm 17.46 \mu \mathrm{g} / \mathrm{mL}$ than of $786 \mathrm{O}$ cells with an IC50 of $173.55 \pm 5.34 \mu \mathrm{g} / \mathrm{mL}$ and of A2058 cells with an IC50 of $227.40 \pm 27.20 \mu \mathrm{g} / \mathrm{mL}$, suggesting that the Maytenus compound could exhibit a favorable anti-lung cancer and anti-cervical cancer effect. However, the Maytenus compound had low cytotoxicity in the human normal epithelial cell lines $16 \mathrm{HBE}$ with an IC50 of 4,555.86 $\pm 25.21 \mu \mathrm{g} / \mathrm{mL}$ and Hecate with an IC50 of $833.56 \pm 181.88 \mu \mathrm{g} / \mathrm{mL}$ (Figure $1 B$ ). According to the IC50 values of the Maytenus compound in the four cancer cell lines at $72 \mathrm{~h}$, we chose the H226 and HeLa cells lines to 

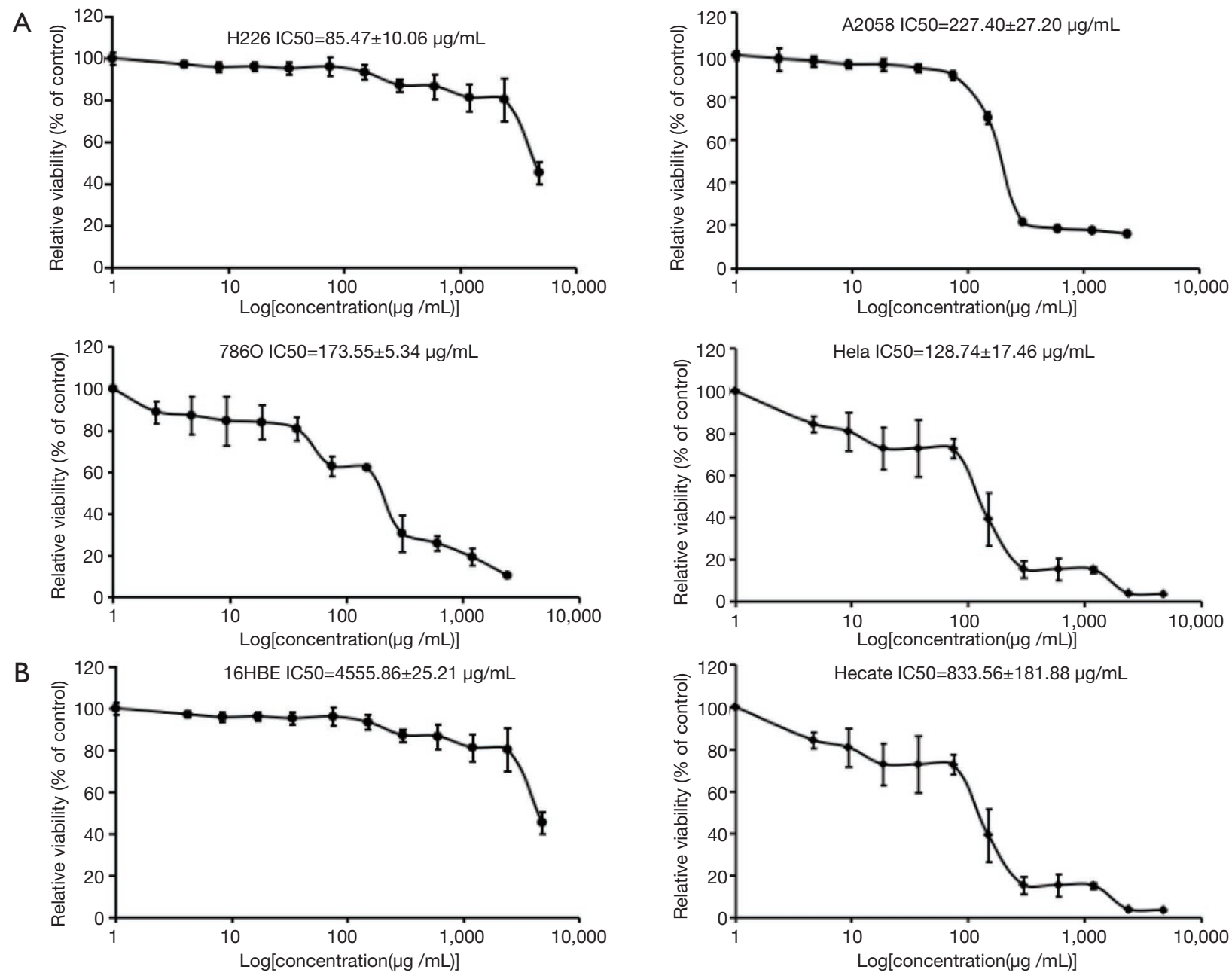

Figure 1 Effect of Maytenus compound on human cancer cells and normal cells. (A) IC50 of the Maytenus compound against H226, A2058, $786 \mathrm{O}$ and HeLa human cancer cells at $72 \mathrm{~h}$ (the mean \pm SD, n=5); (B) IC50 of the Maytenus compound against 16HBE and Hecate human normal epithelial cells at $72 \mathrm{~h}$ (the mean $\pm \mathrm{SD}, \mathrm{n}=5$ ).

continue the study of antitumor activity of the Maytenus compound. Then, we selected $0,30,60$ and $120 \mu \mathrm{g} / \mathrm{mL}$ Maytenus compound concentration to treat $\mathrm{H} 226$ cells and selected $0,50,100$ and $200 \mu \mathrm{g} / \mathrm{mL}$ concentration to treat HeLa cells.

\section{The Maytenus compound had anti-activity effects on $\mathrm{H} 226$ and HeLa cells}

After H226 and HeLa cells were treated as mentioned above, MTS assay was detected the cell viabilities. As shown in Figure $2 A$, the Maytenus compound inhibited the cell growth significantly, the cell viabilities of H226 and HeLa cells were decreased with the increased in
Maytenus compound concentration and were decreased with the increased in Maytenus compound treatment time. In addition, as shown in Figure 2B, there was no statistically difference in $\mathrm{H} 226$ cells treated with $30 \mu \mathrm{g} / \mathrm{mL}$ Maytenus compound at 24, 48, 72 or $96 \mathrm{~h}$. Additionally, there was no statistically difference in HeLa cells treated with $50 \mu \mathrm{g} / \mathrm{mL}$ Maytenus compound at 24, 48, 72 and 96 h. Additionally, there were no statistically differences in H226 cells treated with 60 and $120 \mu \mathrm{g} / \mathrm{mL}$ Maytenus compound at $48 \mathrm{~h}$. However, the cell viabilities were significantly inhibited in $\mathrm{H} 226$ cells treated with 60 and $120 \mu \mathrm{g} / \mathrm{mL}$ Maytenus compound at 72 and $96 \mathrm{~h}$ and in HeLa cells treated with 100 and $200 \mu \mathrm{g} / \mathrm{mL}$ Maytenus compound at 48, 72 and $96 \mathrm{~h}$. 

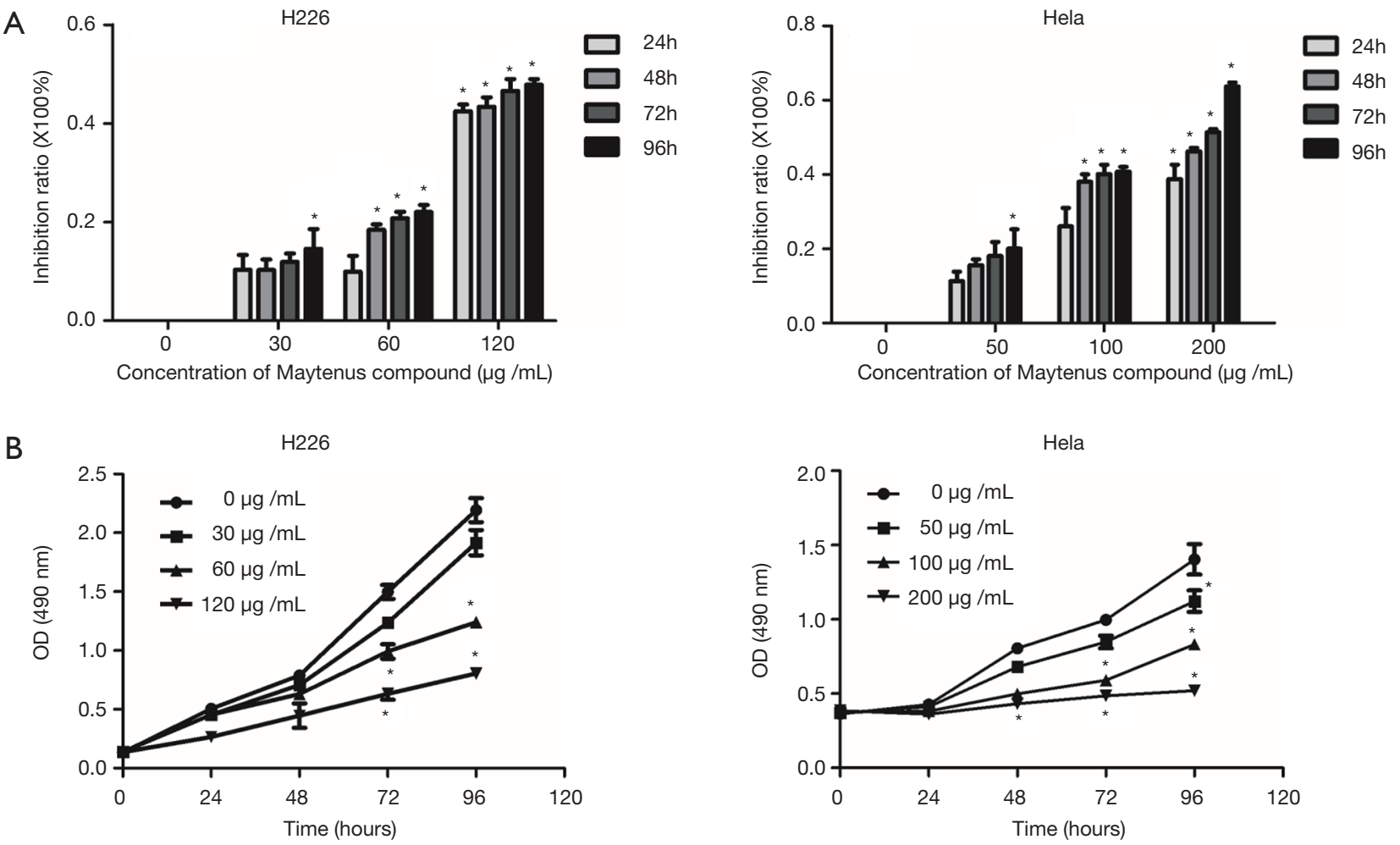

Figure 2 The Maytenus compound possessed anti-activity effects on cancer cells. (A) The Maytenus compound inhibited H226 and HeLa cells proliferation in a mode which is time and dose-dependent. The inhibition rate was calculated according to formula: 1-Experimental group absorbance/Control group absorbance $\times 100 \%$; (B) cell growth viability curves indicate that the Maytenus compound reduced the cells viability significantly. ${ }^{*}, \mathrm{P}<0.05$.

\section{Clonogenic assays}

As shown in Figure 3, after H226 and HeLa cells were treated with the Maytenus compound for $72 \mathrm{~h}$, the cells' clone formation capacity was reduced significantly compared with that of the control cells. Additionally, the clone numbers of the H226 and HeLa cells decreased with the increase in the Maytenus compound concentration. It indicates that the Maytenus compound had anti-clonogenic cancer cell ability.

\section{In vivo antitumor activity}

Nude mice were intragastrically administered the Maytenus compound at doses of $2.45 \mathrm{~g} / \mathrm{kg}$ every day. As shown in Figure 4, the Maytenus compound inhibited H226 cells and HeLa cells tumor growth in the mouse models. Compared to control group, the inhibition effects in the experiment group were significant $(\mathrm{P}<0.05)$, the inhibition rates for tumor growth were $36.06 \%$ and $26.45 \%$ for the H226 mouse models and HeLa mouse models, respectively (Table 1). The tumor weight results also indicated the antitumor activity of the Maytenus compound in vivo. Furthermore, the Maytenus compound had no significant effect on the mouse bodyweight, liver index, spleen index and kidney index. These results clearly showed that the Maytenus compound had a significant anticancer effect in vivo.

\section{HE staining analysis}

As shown in Figure 5, in the control groups, the tumor cells volume was large and round, nucleoli large and distinct, the cell structure was clear and intact, suggesting good growth. However, in the Maytenus compound groups, the tumor cells showed degenerative changes, karyopyknosis and fibrosis; in the solid tumor from the HeLa Maytenus compound groups, necrosed area could be found, where the structure showed loss of nuclei and fragmentation of 

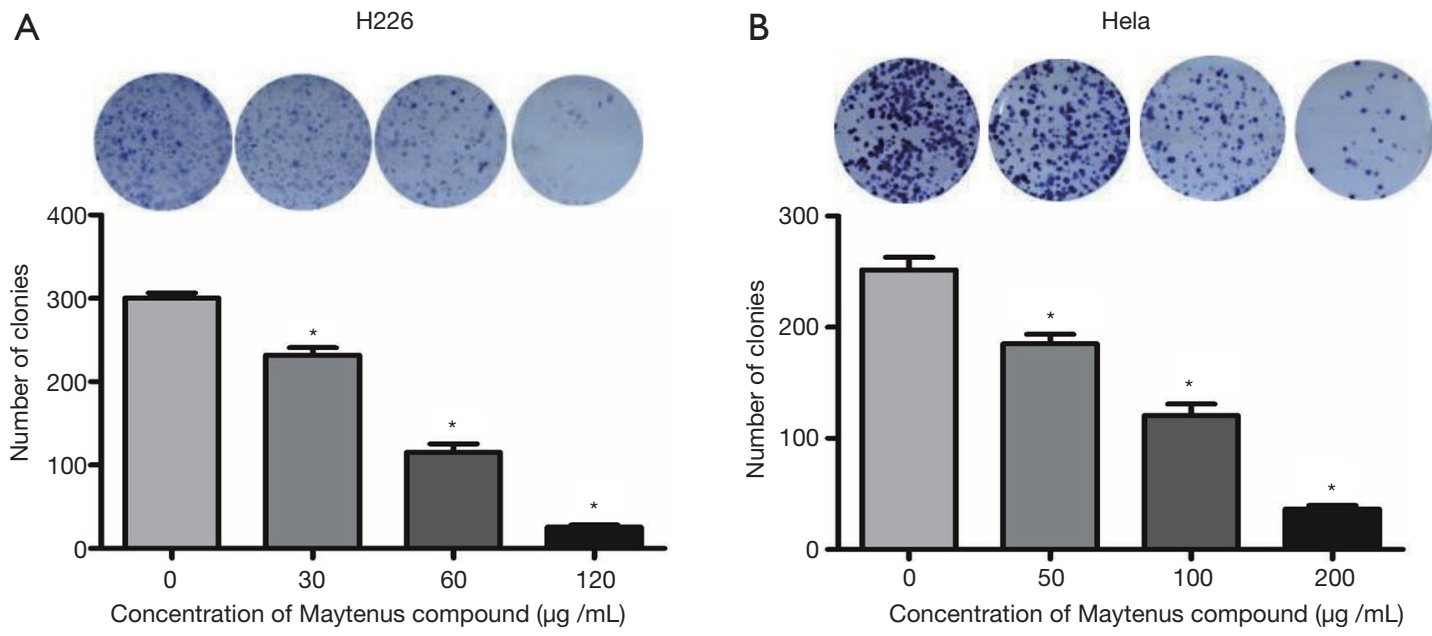

Figure 3 The Maytenus compound had anti-clonogenic effects on cancer cells, hematoxylin staining. (A) The Maytenus compound inhibited clone formation in H226 cells with a dose-dependent mode; (B) the Maytenus compound inhibited clone formation in HeLa cells with a dose-dependent mode. *, $\mathrm{P}<0.05$.
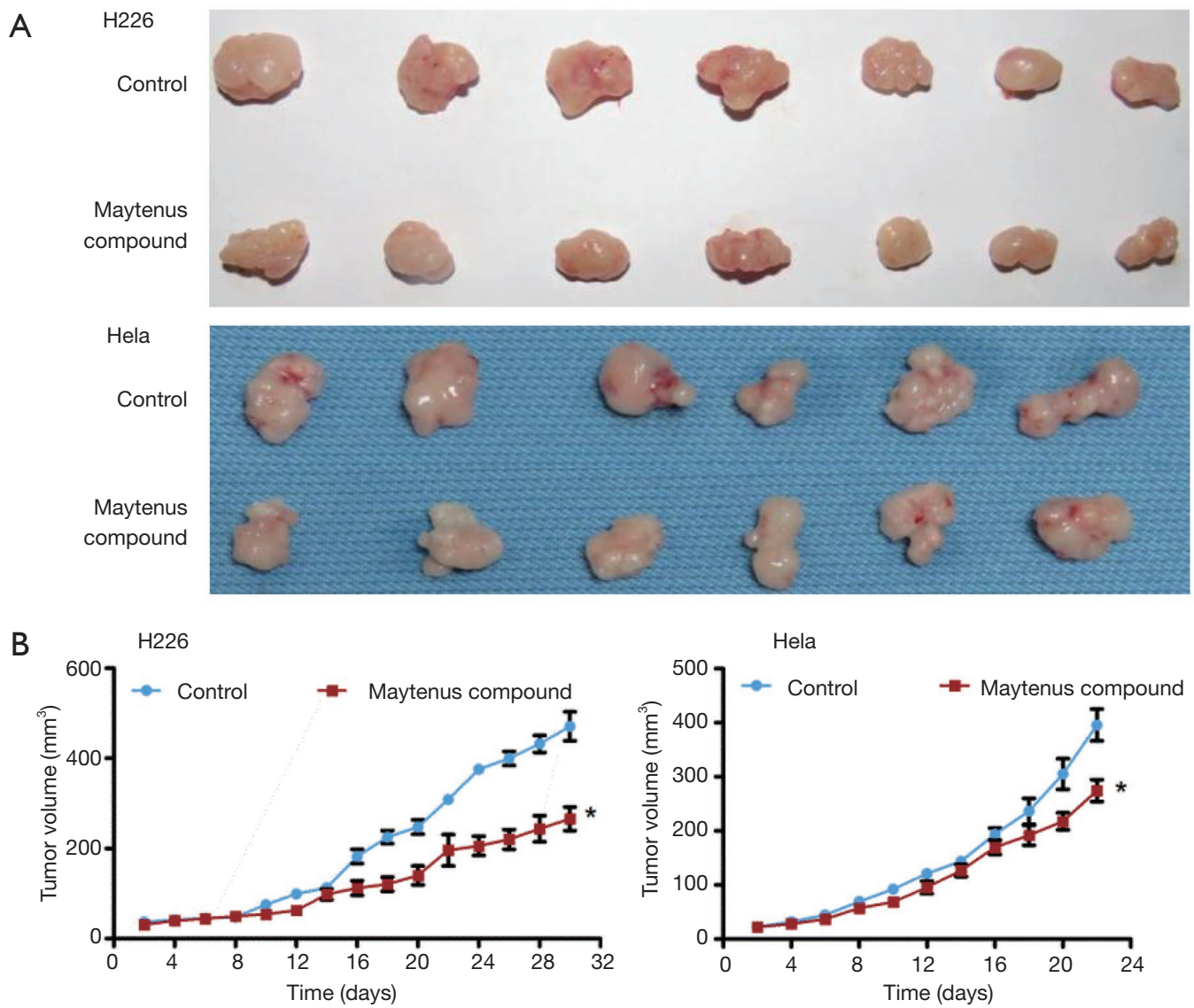

Figure 4 Antitumor activity of the Maytenus compound in vivo. After inoculation with cancer cells for 1 week, mice were intragastrically administered the Maytenus compound at dose of $2.45 \mathrm{~g} / \mathrm{kg} /$ day. (A) Tumor size was recorded; (B) tumor volume was recorded. Data are presented as the means $\pm \mathrm{SD}, \mathrm{n}=7$. *, $\mathrm{P}<0.05$. 
Table 1 The antitumor effect of the Maytenus compound in vivo

\begin{tabular}{|c|c|c|c|c|}
\hline Groups & \multicolumn{2}{|c|}{$\mathrm{H} 226$} & \multicolumn{2}{|c|}{ HeLa } \\
\hline Body weight (g) beginning & $13.49 \pm 0.54$ & $13.93 \pm 0.56$ & $14.85 \pm 1.11$ & $14.79 \pm 1.17$ \\
\hline Body weight (g) ending & $14.97 \pm 0.81$ & $14.01 \pm 1.10$ & $15.72 \pm 1.85$ & $14.07 \pm 1.38$ \\
\hline Tumor volume $\left(\mathrm{cm}^{3}\right)$ & $4.95 \pm 0.95$ & $2.81 \pm 0.76$ & $3.96 \pm 0.72$ & $2.81 \pm 0.84$ \\
\hline Inhibitory rate (\%) & - & $36.06^{*}$ & - & $26.45^{\star}$ \\
\hline Liver index & $6.12 \pm 0.43$ & $6.09 \pm 0.19$ & $6.11 \pm 0.32$ & $6.54 \pm 0.53$ \\
\hline Spleen index & $0.59 \pm 0.05$ & $0.61 \pm 0.14$ & $0.70 \pm 0.15$ & $0.70 \pm 0.06$ \\
\hline Kidney index & $1.52 \pm 0.06$ & $1.58 \pm 0.05$ & $1.53 \pm 0.11$ & $1.65 \pm 0.28$ \\
\hline
\end{tabular}

The Organ Index was calculated according to formula: Organ weight/Body weight $\times 100 \%$., $\mathrm{P}<0.05$.
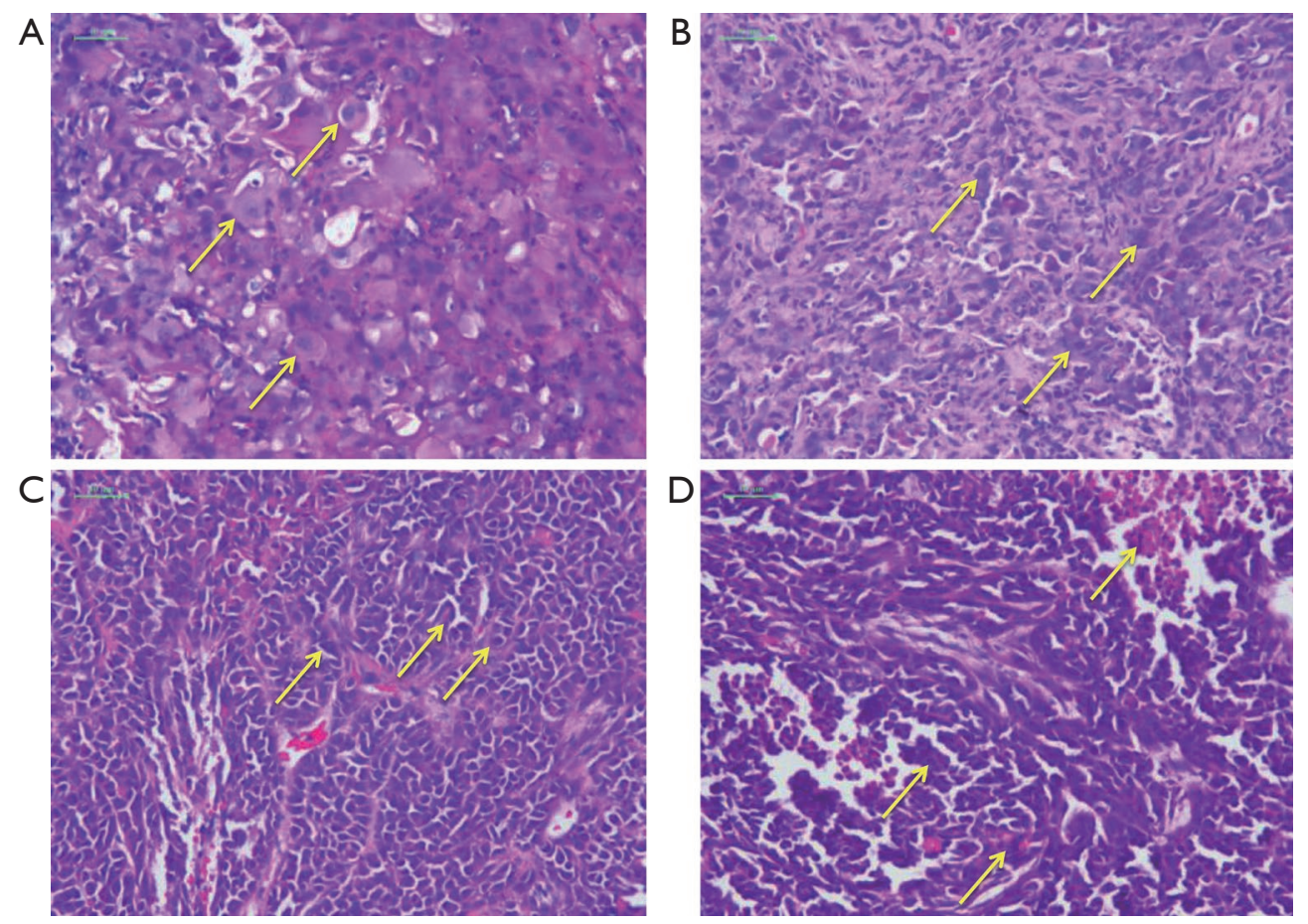

Figure $5 \mathrm{HE}$ staining of tumor tissue slices from mice $(\times 200)$. (A) H226 control. Arrow indicating morphologically intact tumor cells with large cell volume, large and distinct nucleoli; (B) H226 Maytenus compound. Arrow indicating degenerative changes tumor cells with small cell volume, concentrated nucleus and plasma; (C) HeLa control. Arrow indicating morphologically intact tumor cells with large cell volume, large and distinct nucleoli; (D) HeLa Maytenus compound. Arrow indicating degenerative changes and necrotic tumor cells with small cell volume, concentrated nucleus and plasma. 

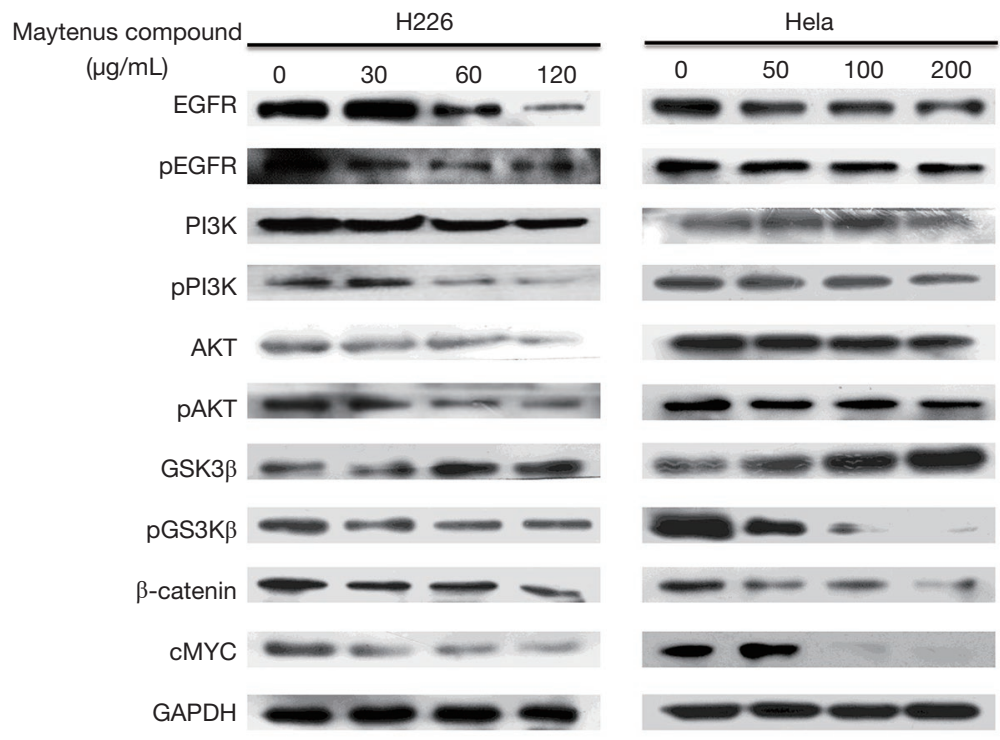

Figure 6 Western blot. Changes in expression levels of EGFR, pEGFR, PI3K, pPI3K, AKT, pAKT, GSK3 $\beta$, pGSK3 $\beta$, $\beta$-catenin and c-MYC proteins in $\mathrm{H} 226$ and HeLa cells after $72 \mathrm{~h}$ treatment with the Maytenus compound.

cells. The results indicated the Maytenus compound had anticancer ability in vivo.

\section{Western blot analysis}

To further understand the antitumor activity of Maytenus compound on H226 and HeLa cells, western blot was used to analyze proteins change in cells treated with the Maytenus compound for $72 \mathrm{~h}$. As shown in Figure 6, the Maytenus compound reduced the level of EGFR, pEGFR, pPI3K, pAKT, pGSK3 $\beta, \beta$-catenin and c-MYC protein and increased protein expression of GSK3 $\beta$ in a dose-dependent manner. These results indicated that the Maytenus compound could inhibit proliferation of H226 and HeLa cells by down-regulating the phosphorylation levels of EGFR, PI3K, AKT and GSK3 3 .

\section{Discussion}

Numerous valuable "treasures" from Chinese traditional medicine were discovered because of the development of science and technology, especially national herbal medicine $(12,13)$. Some Chinese traditional medicine substances have been proven to possess anticancer properties without side effects, such as dihydroartemisinin (14). In addition, in China, Chinese herbal medicine products as antitumor agents have thousand-years of history. In our study, the antitumor activity of the Maytenus compound against four cancer cell lines, including H226, A2058, $786 \mathrm{O}$ and HeLa, were confirmed in a dose-dependent manner, and these effects on H226 and HeLa were also confirmed in a timedependent manner. Additionally, the Maytenus compound showed low toxicity in human normal epithelial cells, and the results are consistent with those of Nkosinathi, who reported that the methanolic root extracts of Maytenus procumbens exhibited moderate cytotoxic effects on the cancer and weak cytotoxicity in the normal cells (15). In addition, the Maytenus compound had the ability to control $\mathrm{H} 226$ and HeLa cell proliferation in nude mice in vivo without cytotoxicity. The result indicated that the Maytenus compound could be a potential natural and novel anticancer drug, especially for lung cancer and cervical cancer.

Lung cancer has high morbidity and mortality worldwide (1). Cervical cancer is the fourth in cancer related mortality among all cancer types and second in cancer related mortality among females $(16,17)$, highlighting the importance of studying the antitumor mechanism of the Maytenus compound. Some reports have shown that some extracts of Maytenus have an antitumor mechanism, such as pristimerin, a natural triterpenoid isolated from Celastrus and Maytenus spp, which has been found to inhibit tumor cells in vitro and in vivo, and affect the proliferation, survival, angiogenesis and metastasis though the NF-kB, MAPK/ERK and AKT/mTOR pathways (18). Additionally, 
the methanol extract of Maytenus royleanus leaves and its fractions possess anti-proliferative activity against prostate cancer by exhibiting cleavage of Caspase-3 and PARP (19). As the derivative of maytansine, T-DM1 combined with pertuzumab significantly inhibited the phosphorylation of HER3 or EGFR, and its downstream factor AKT inhibited gastric cancer proliferation (20).

The EGFR is a tyrosine kinase receptor that belongs to the Erb family, which is overexpressed in many tumor types, including lung cancer and cervical cancer $(21,22)$. EGFR plays an important role in the physiological processes of the development and maintenance of epithelial tissues, and upregulated EGFR expression can activate cell proliferation and differentiation signaling pathways that lead to the progression of cancer, increase the metastasis and the suppression of apoptosis and angiogenesis (23-25). Drugs that affect the activity of EGFR have been used in clinical practice for cancer therapy $(26,27)$. The major molecular mechanism of EGFR-induced tumor progression is that EGFR kinase phosphorylation activates the PI3K/ AKT signaling pathway (28). PI3K phosphorylates the 3-hydroxyl of phosphatidylinositol, regulating proliferation, survival and metastasis signaling pathways, which are important for cancer (29-31). AKT (AK mouse plus transforming or thymoma), as a downstream component of the PI3K pathway, is a fundamental protein mediating signals from the receptor tyrosine kinases family, it is a frequent oncogene (32,33). Consistent with these data, western blot was used to evaluate the expression of the EGFR, pEGFR, PI3K, pPI3K, AKT, and pAKT proteins in the cells with the Maytenus compound treatment, and we obtained evidence that the Maytenus compound reduced the levels of the EGFR, pEGFR, PI3K, pPI3K, AKT, and pAKT proteins. These data collectively indicate that the Maytenus compound triggers the EGFR/PI3K/AKT signaling pathways.

The underlying downstream mechanism of the Maytenus compound in inhibiting the proliferation of cancer cells though the EGFR/PI3K/AKT signaling pathways still need to elucidate furtherly, many studies have reported that PI3K/AKT is the upstream regulatory pathway of the GSK3 $\beta / \beta$-catenin protein combination related with cell proliferation (34-36). Activated AKT translocates to the cell membrane, phosphorylating serine/threonine kinase glycogen synthase kinase $3 \beta$ (GSK3 $\beta$ ) $(37,38)$. Under normal physiological conditions, GSK3 $\beta$ is highly expressed, and its main role is to destroy the complex containing APC and Axin, promote the decomposition of $\beta$-catenin and weaken the stability of $\beta$-catenin; however, GSK3 $\beta$ is less expressed in cancer cells, which promotes the stability of $\beta$-catenin $(39,40)$. Then, $\beta$-catenin can enter the nucleus and activate its target genes, including c-MYC (41). Additionally, we found that the Maytenus compound significantly inhibited the expression of pGSK3 $\beta, \beta$-catenin and $c-M Y C$ and promoted the expression of GSK3 $\beta$.

In conclusion, the Maytenus compound is a Chinese six-herb medicine, which possesses favorable inhibitory activity against the growth of human H226, A2058, $786 \mathrm{O}$ and HeLa cancer cells in vitro, especially against $\mathrm{H} 226$ and HeLa. The Maytenus compound inhibits the growth of H226 and HeLa xenografts in vivo.

In addition, we found that the Maytenus compound played a role in anticancer activity via the EGFR/PI3K/AKT/GSK3 $\beta$ pathway, and many of the traditional Chinese medicines have been shown to have anticancer activity through multiple targets $(42,43)$; therefore, the Maytenus compound might have other pathways. Next, we further studied its anticancer mechanism. Maytansine has a high inhibition effect on cancer, but using it alone has hepatotoxicity, and it has been assessed in several oncology clinical trials (44). However, in this study, the Maytenus compound had a low cytotoxicity in human normal epithelium cells and no toxicity in mouse organs. Therefore, the Maytenus compound could be a potential treatment agent for lung cancer and cervical cancer. However, before it can proceed further in preclinical tests, considerations such as safety evaluations, pharmacokinetics and a suitable oral administration dosage should be investigated.

\section{Conclusions}

Taken together, our results indicate that the Maytenus compound has significant anticancer activities against human cancer H226 and HeLa cells both in vitro and in vivo, highlighting it could be a novel potential anticancer drug.

\section{Acknowledgments}

Funding: This work was supported by the National Natural Science Foundation of China (No. U1502222, U81673463 and U81602029); the Applied Basic Research Foundation of Yunnan Province Science and Technology Department \& Kunming Medical University (2018FE001(-249); and the Yunnan Province-Kunming Medical University joint Foundation for Applied Basic Research (2015FB074).

\section{Footnote}

Conflicts of Interest: All authors have completed the ICMJE uniform disclosure form (available at http://dx.doi. 
org/10.21037/tcr.2019.09.30). The authors have no conflicts of interest to declare.

Ethical Statement: The authors are accountable for all aspects of the work in ensuring that questions related to the accuracy or integrity of any part of the work are appropriately investigated and resolved. This study was conducted in accordance with the Declaration of Helsinki (as revised in 2013). The animal experiments were performed in accordance with the institutional ethical requirements of the Kunming Medical University and approved by the Ethics Committee of Kunming Medical University (No. KMMU2019060). Individual informed consent was waived.

Open Access Statement: This is an Open Access article distributed in accordance with the Creative Commons Attribution-NonCommercial-NoDerivs 4.0 International License (CC BY-NC-ND 4.0), which permits the noncommercial replication and distribution of the article with the strict proviso that no changes or edits are made and the original work is properly cited (including links to both the formal publication through the relevant DOI and the license). See: https://creativecommons.org/licenses/by-nc-nd/4.0/.

\section{References}

1. Siegel RL, Miller KD, Jemal A. Cancer statistics, 2018. CA Cancer J Clin 2018;68:7-30.

2. Khan MA, Ali R, Parveen R, et al. Pharmacological evidences for cytotoxic and antitumor properties of Boswellic acids from Boswellia serrata. J Ethnopharmacol 2016;191:315-23.

3. Cipriani TR, Mellinger CG, de Souza LM, et al. A polysaccharide from a tea (infusion) of Maytenus ilicifolia leaves with anti-ulcer protective effects. J Nat Prod 2006;69:1018-21.

4. Leite JP, Rastrelli L, Romussi G, et al. Isolation and HPLC quantitative analysis of flavonoid glycosides from Brazilian beverages (Maytenus ilicifolia and M. aquifolium). J Agric Food Chem 2001;49:3796-801.

5. Momtaz S, Hussein AA, Ostad SN, et al. Growth inhibition and induction of apoptosis in human cancerous HeLa cells by Maytenus procumbens. Food Chem Toxicol 2013;51:38-45.

6. Araújo Júnior RF, Oliveira AL, Pessoa JB, et al. Maytenus ilicifolia dry extract protects normal cells, induces apoptosis and regulates Bcl-2 in human cancer cells. Exp Biol Med (Maywood) 2013;238:1251-8.

7. Kupchan SM, Komoda Y, Court WA, et al. Maytansine, a novel antileukemic ansa macrolide from Maytenus ovatus.
J Am Chem Soc 1972;94:1354-6.

8. Remillard S, Rebhun LI, Howie GA, et al. Antimitotic activity of the potent tumor inhibitor maytansine. Science 1975;189:1002-5.

9. Boyraz B, Sendur MA, Aksoy S, et al. Trastuzumab emtansine (T-DM1) for HER2-positive breast cancer. Curr Med Res Opin 2013;29:405-14.

10. Su J, Zhao P, Kong L, et al. Trichothecin induces cell death in NF-kappaB constitutively activated human cancer cells via inhibition of IKKbeta phosphorylation. PLoS One 2013;8:e71333.

11. Buck E, Eyzaguirre A, Brown E, et al. Rapamycin synergizes with the epidermal growth factor receptor inhibitor erlotinib in non-small-cell lung, pancreatic, colon, and breast tumors. Mol Cancer Ther 2006;5:2676-84.

12. Tu X, Deng Y, Chen J, et al. Screening study on the antiangiogenic effects of Traditional Chinese Medicine - Part I: Heat-clearing and detoxicating TCM. J Ethnopharmacol 2016;194:280-7.

13. Xu Y, Chen X, Chen X, et al. San Huang Decoction downregulates Aurora kinase A to inhibit breast cancer cell growth and enhance chemosenstivity to anti-tumor drugs. Pathol Res Pract 2016;212:696-703.

14. Qu C, Ma J, Liu X, et al. Dihydroartemisinin Exerts AntiTumor Activity by Inducing Mitochondrion and Endoplasmic Reticulum Apoptosis and Autophagic Cell Death in Human Glioblastoma Cells. Front Cell Neurosci 2017;11:310.

15. Cele ND, Sangweni NF, Mosa RA, et al. Testicular Dysfunction Ameliorative Effect of the Methanolic Roots Extracts of Maytenus procumbens and Ozoroa paniculosa. Evid Based Complement Alternat Med 2017;2017:8204816.

16. Torre LA, Bray F, Siegel RL, et al. Global cancer statistics, 2012. CA Cancer J Clin 2015;65:87-108.

17. Wright TC Jr, Kuhn L. Alternative approaches to cervical cancer screening for developing countries. Best Pract Res Clin Obstet Gynaecol 2012;26:197-208.

18. Yousef BA, Hassan HM, Zhang LY, et al. Anticancer Potential and Molecular Targets of Pristimerin: A MiniReview. Curr Cancer Drug Targets 2017;17:100-8.

19. Shabbir M, Syed DN, Lall RK, et al. Potent antiproliferative, pro-apoptotic activity of the Maytenus royleanus extract against prostate cancer cells: evidence in in-vitro and in-vivo models. PLoS One 2015;10:e0119859.

20. Yamashita-Kashima Y, Shu S, Harada N, et al. Enhanced antitumor activity of trastuzumab emtansine (T-DM1) in combination with pertuzumab in a HER2-positive gastric cancer model. Oncol Rep 2013;30:1087-93.

21. Park IK, Hyun K, Kim ER, et al. The prognostic effect 
of the epidermal growth factor receptor gene mutation on recurrence dynamics of lung adenocarcinoma. Eur J Cardiothorac Surg 2018;54:1022-7.

22. Wei H, Zhu Z, Lu L. Inhibition of EGFR nuclear shuttling decreases irradiation resistance in HeLa cells. Folia Histochem Cytobiol 2017;55:43-51.

23. Hosur V, Farley ML, Burzenski LM, et al. ADAM17 is essential for ectodomain shedding of the EGF-receptor ligand amphiregulin. FEBS Open Bio 2018;8:702-10.

24. Masroor M, Mir R, Javid J, et al. Cell Free EGFR mRNA Expression and Implications for Survival and Metastasis in Non-Small Cell Lung Cancer Cases. Asian Pac J Cancer Prev 2015;16:6445-9.

25. Xu L, Qu X, Li H, et al. Src/caveolin-1-regulated EGFR activation antagonizes TRAIL-induced apoptosis in gastric cancer cells. Oncol Rep 2014;32:318-24.

26. Yang JC, Sequist LV, Geater SL, et al. Clinical activity of afatinib in patients with advanced non-small-cell lung cancer harbouring uncommon EGFR mutations: a combined post-hoc analysis of LUX-Lung 2, LUX-Lung 3, and LUX-Lung 6. Lancet Oncol 2015;16:830-8.

27. Nogueira-Rodrigues A, Moralez G, Grazziotin R, et al. Phase 2 trial of erlotinib combined with cisplatin and radiotherapy in patients with locally advanced cervical cancer. Cancer 2014;120:1187-93.

28. Gao Y, Yu H, Liu Y, et al. Long Non-Coding RNA HOXA-AS2 Regulates Malignant Glioma Behaviors and Vasculogenic Mimicry Formation via the MiR-373/EGFR Axis. Cell Physiol Biochem 2018;45:131-47.

29. Liu Q, Liang X, Niu C, et al. Ellagic acid promotes A549 cell apoptosis via regulating the phosphoinositide 3-kinase/ protein kinase B pathway. Exp Ther Med 2018;16:347-52.

30. Ni J, Peng Y, Yang FL, et al. Overexpression of CLEC3A promotes tumor progression and poor prognosis in breast invasive ductal cancer. Onco Targets Ther 2018;11:3303-12.

31. Zhao W, Sun Q, Yu Z, et al. MiR-320a-3p/ELF3 axis regulates cell metastasis and invasion in non-small cell lung cancer via PI3K/Akt pathway. Gene 2018;670:31-7.

32. Chin YR, Yuan X, Balk SP, et al. PTEN-deficient tumors depend on AKT2 for maintenance and survival. Cancer Discov 2014;4:942-55.

33. Vivanco I, Chen ZC, Tanos B, et al. A kinase-independent function of AKT promotes cancer cell survival. Elife 2014. doi: 10.7554/eLife.03751.

34. Tang Q, Zheng X, Zhang J. Long non-coding RNA CRNDE promotes heptaocellular carcinoma cell proliferation by regulating $\mathrm{PI} 3 \mathrm{~K} / \mathrm{Akt} /$ beta-catenin signaling. Biomed Pharmacother 2018;103:1187-93.

35. Shu T, Liu C, Pang M, et al. Salvianolic acid B promotes neural differentiation of induced pluripotent stem cells via PI3K/AKT/GSK3beta/beta-catenin pathway. Neurosci Lett 2018;671:154-60.

36. Song Z, Han X, Shen L, et al. PTEN silencing enhances neuronal proliferation and differentiation by activating PI3K/Akt/GSK3beta pathway in vitro. Exp Cell Res 2018;363:179-87.

37. Hu W, Xiao L, Cao C, et al. UBE2T promotes nasopharyngeal carcinoma cell proliferation, invasion, and metastasis by activating the AKT/GSK3beta/beta-catenin pathway. Oncotarget 2016;7:15161-72.

38. Lv J, Wei Y, Chen Y, et al. Dexmedetomidine attenuates propofol-induce neuroapoptosis partly via the activation of the PI3k/Akt/GSK3beta pathway in the hippocampus of neonatal rats. Environ Toxicol Pharmacol 2017;52:121-8.

39. Lee SK, Hwang JH, Choi KY. Interaction of the Wnt/ beta-catenin and RAS-ERK pathways involving costabilization of both beta-catenin and RAS plays important roles in the colorectal tumorigenesis. Adv Biol Regul 2018;68:46-54.

40. Meffre D, Grenier J, Bernard S, et al. Wnt and lithium: a common destiny in the therapy of nervous system pathologies? Cell Mol Life Sci 2014;71:1123-48.

41. Deng X, Hamamoto R, Vougiouklakis T, et al. Critical roles of SMYD2-mediated beta-catenin methylation for nuclear translocation and activation of Wnt signaling. Oncotarget 2017;8:55837-47.

42. Xu H, Zhao X, Liu X, et al. Antitumor effects of traditional Chinese medicine targeting the cellular apoptotic pathway. Drug Des Devel Ther 2015;9:2735-44.

43. Chen $\mathrm{Y}, \mathrm{Wu} \mathrm{H}$, Wang X, et al. Huaier Granule extract inhibit the proliferation and metastasis of lung cancer cells through down-regulation of MTDH, JAK2/STAT3 and MAPK signaling pathways. Biomed Pharmacother 2018;101:311-21.

44. Taplin S, Vashisht K, Walles M, et al. Hepatotoxicity with antibody maytansinoid conjugates: A review of preclinical and clinical findings. J Appl Toxicol 2018;38:600-15.

Cite this article as: Zeng $\mathrm{B}, \mathrm{Ge} \mathrm{C}$, Zhao $\mathrm{W}, \mathrm{Fu} \mathrm{K}$, Liu L, Lin Z, Fu Q, Li Z, Li R, Guo H, Li C, Zhao L, Hu H, Yang H, Huang W, Huang Y, Song X. Anticancer effect of the traditional Chinese medicine herb Maytenus compound via the EGFR/PI3K/AKT/GSK3 $\beta$ pathway. Transl Cancer Res 2019;8(5):2130-2140. doi: 10.21037/tcr.2019.09.30 